\title{
Bitkilendirilmiş Çatı Sistemlerinin Türkiye'de Yaygınlaşamama Nedenleri Üzerine Bir Araştırma
}

\author{
Ülger BULUT KARACA ${ }^{1}$
}

Öz

Bitkilendirilmiş çatıların çevresel, ekonomik ve sosyal faydalara sahip olduğu kabul edilmektedir. Hızıı kentleşme yaşayan Türkiye, bitkilendirilmiş çatıların faydalarını kazanma potansiyeline sahiptir. Ancak bitkilendirilmiş çatı sistemi uygulamalarının Türkiye'de yaygınlaşamadığı görülmektedir. Bu nedenle, bitkilendirilmiş çatı sistemlerinin Türkiye'de yaygınlaşmasının önündeki engellerin neler olduğu konusunda belirlenen temel sınırlar dahilinde araştırma ve inceleme yapılmasına gerek duyulmuştur. Kentsel alanlardaki yoğun yapılaşmanın ısı adası oluşumuna etkisi göz önünde bulundurularak bu çalışma kapsamında, yüksek yapı yoğunluğuna sahip yerleşim alanlarında bitkilendirilmiş çatı sistemlerinin yaygınlaştırılması amaç olarak belirlenmiştir. Literatür taraması ile bitkilendirilmiş çatı sistemlerinin dünyada yaygınlaşmasının önündeki engeller tespit edilmiştir. Bu engellerin Türkiye'deki geçerliliklerini belirlemek amacıyla, yatırımcı, iş geliştirici, mimar, peyzaj mimarı, danışman, tedarikçi, uygulamacı ve denetçi olmak üzere farklı faaliyet alanlarından toplam 16 bitkilendirilmiş çatı konusunda uzman ile derinlemesine mülakat gerçekleştirilmiştir. Mülakatların sonucunda belirlenen bitkilendirilmiş çatı sistemlerinin yaygınlaşmasının önündeki engellerin sektör paydaşlarına göre önem sırasını belirlemek amacıyla, 47 katılımcının olduğu bir anket düzenlenmiştir. Sonuç olarak Türkiye'de BÇS'nin; ekolojik bağlamdaki katkılarının yeterince önemsenmediği, yatırım maliyetlerinin yüksek bulunduğu, görselliği nedeniyle bir pazarlama unsuru olarak görüldüğü sonuçlarına varılmıştır.

Anahtar Kelimeler: bitkilendirilmiş çatı sistemleri, yeşil çatılar, kentsel ısı adası

\section{A Study on the Causes that Keep the Vegetated Roofing System Applications from Spreading in Turkey}

\begin{abstract}
\footnotetext{
${ }^{1}$ İstanbul AREL Üniversitesi, Mühendislik-Mimarlık Fakültesi

* İlgili yazar/Corresponding author: ulgerbulut@hotmail.com

Gönderim Tarihi / Received Date: 24.07.2020

Kabul Tarihi / Accepted Date: 03.12.2020
}

Vegetated roofs are considered to have environmental, economic and social benefits. Turkey, with an accelerated urbanization, has a potential to gain the benefits of vegetated roofing. However, vegetated roofing systems do not seem to be widespread in practice in Turkey. Therefore, it has been deemed a requirement to make a research and investigation within the basic limits of the things keeping vegetated roofing systems from becoming widespread. The purpose of this study is providing the usage of vegetated roofing systems to become widespread in urban areas of intensive housing, considering the role of intensive structured urban areas in the causes of heat island formations. For this purpose, primarily, a determination has been made with a literature review, for the barriers keeping the spread of vegetated roofing systems in the world. In order to determine the validity of those barriers in Turkey, in-depth interviews were held with 16 experts of vegetated roofing, including investors, business developers, 
architects, landscape architects, consultants, suppliers, practitioners and supervisors. As the next step, a questionnaire with 47 participants of sectoral stakeholders was held to determine the order of importance among the barriers obtained as a result of the indepth interviews. Consequently, it has been determined that VRS isn't taken seriosly enough in Turkey in terms of ecological contributions and is considered a high investment cost but also seen as a marketing advantage due to its visuality.

Keywords: Vegetated roofing systems, green roofs, urban heat island 1. GiRiş

Günümüzde iklim değişimi ve buna bağlı sorunlar tüm dünyanın önemli gündem maddelerinden biridir. Kentleşmenin artması sonucu, doğal bitki örtüsü ve su alanları yerlerini ısı depolama kapasitesi yüksek ve su geçirimsiz kentsel yüzeylere bırakmakta; böylece kentsel alanlarda, kırsal alanlara oranla sıcaklık artışı başka bir deyişle, kentsel ısı adaları oluşmaktadır.

EPA (Environmental Protection Agency - Çevre Koruma Ajansı), bitki örtüsünün azalması, hava sirkülasyonunun sınırlanması ve yayılan aşırı ısı nedeniyle bazı ABD şehirlerinin, çevre banliyölerinden veya kırsal alanlardan 5,5 C (10 F) daha yüksek hava sıcaklıklarına sahip olduğunu belirlemiştir (EPA, 2007). Kentsel ısı adası etkisiyle kış aylarında kentsel alanlarda hissedilen hava sıcaklıklarındaki artış, binaların ısı kayıplarını düşürdüğü için ısınma amaçlı enerji tüketiminde azalmaya neden olur. Ancak yaz aylarında, kentsel ısı adası nedeniyle kentsel alanlarda artan hava sıcaklığı, binalarda soğutma amaçlı enerji gereksinimini artırmakta ve sağlık sorunlarına neden olabilmektedir. Isı adası etkisi ile Atina'daki binaların soğutma yükünün iki kat, elektrik gereksiniminin ise üç kat arttığı tespit edilmiştir (Santamouris, 2001, 103). Devlet Meteoroloji İşleri'nin 1951-1990 yılları arasında yaptığı meteorolojik ölçümlere göre, Türkiye'nin batı ve güney batı bölümlerinde daha çok yaz mevsiminde kent ısı adası nedeniyle sıcaklık artışının olduğu ortaya konulmuştur (Türkeri ve ark., 2011, 22).

Günümüzde bitkilendirilmiş çatılar hem enerji tüketimini, hem de kirliliğe dayalı çevre sorunlarını azaltma potansiyeli olan teknolojik bir araç olarak görülmekte ve dünyanın birçok ülkesinde kentsel alanlardaki yeşil alan eksikliğini azaltan uygulamalar olarak değerlendirilmektedirler (Clark ve ark., 2008, 2155).

Bitkilendirilmiş çatı sistemleri (BÇS), en basit açıklama ile çatı kaplama malzemesi yerine, çatı yüzeyinde bitki yetiştirilmesi olarak tanımlanabilir. BÇS, uygulamaları yapılmaya başlandığı yıllarda yabancı dildeki karşılıklarının doğrudan dilimize çevirisi yapılarak "yeşil çatı" ya da "çatı bahçesi" gibi isimlerle adlandırılmıştır (Ekşi, 2014, s. 27). Bu sistemlerde en üstte örtü olarak bitki katmanının bulunması nedeniyle bu çalışmada söz konusu sistem "bitkilendirilmiş çatı sistemi" (BÇS) olarak kabul edilmiştir. Tipik bir BÇS, bitki örtüsü, bitki yetişme katmanı, filtre, drenaj katmanı, yalıtım, kök tutucu su yalıtım membranı ve taşıyıcı katmandan oluşur. BÇS, yük kapasitesi, toprak derinliği, yaya erişimi, sulama ve drenaj sistemi karmaşıklığı, bakım gereksinimi ve bitki örtüsü gibi özellikleri göz önüne alınarak 3 ana grup altında sınıflandırılabilir: yüzeysel bitkilendirilmiş (extensive) çatılar, yarı-yoğun bitkilendirilmiş (semi-intensive) çatılar ve yoğun bitkilendirilmiş (intensive) çatılar.

Yapılan literatür araştırması sonucunda derlenen bitkilendirilmiş çatıların yararlarında kentsel ISı adası etkisinin ve bina ısıtma-soğutma yüklerinin azaltılması, çatı bileşenlerinin atmosferik etkenlerden korunması, yağış sularının kontrollü toplanması, 
gürültü kontrolü, kentsel hava kalitesinin iyileştirilmesi, biyo-çeşitlilik için ortam sağlaması konularına bu çalışmada yer verilmiştir.

Kentsel ISı adası sorunu ile ilişkili olarak bitkilendirilmiş çatılar, yüksek yapı yoğunluğuna sahip kentsel alanlarda (inşaat alanı/yeşil alan) oranının artmasını sağlayarak ısı adası etkisini azaltmaya yardımcı olur. Bitki örtüsü ve yetişme katmanı nem depolar ve ISI, suyun buharlaşmasına yardımcı olur. Bu süreç ortamdaki Isı etkisini azaltır ve serinlik sağlar. "Tokyo merkezli Peyzaj ve Kentsel Yeşil Teknoloji Geliştirme Organizasyonu (Organization for Landscape and Urban Greenery Technology Development), kentteki çatıların yarısının bitkilendirilmiş çatı olması durumunda, sıcak yaz günlerinin gündüz saatlerinde sıcaklıkların $0,84{ }^{\circ} \mathrm{C}$ düşeceğini tahmin etmektedir" (Miaomiao, 2011, 22).

Türkeri ve arkadaşları $(2011,28)$, İstanbul şartlarında bitkilendirilmiş çatı sistemine dönüştürülen mevcut bir teras çatı sistemi ile bitüm örtülü mevcut bir çatı sisteminin performanslarını karşılaştırmak amaçlı bir çalışma yürütmüşlerdir. Çalışmanın ilk sonuçlarına göre ilkbahar mevsiminde yüzeyi henüz bitki ile tam örtülmemiş bitkilendirilmiş çatı sistemi ile mevcut çatı sisteminin güneş ışınım yansıtma oranı yaklaşık olarak aynı olmuştur. Gündüz, öğle saatlerinde bitkilendirilmiş çatı sisteminde toprak yüzey sıcaklık değerleri, mevcut çatı sisteminin yüzey sıcaklık değerlerinden daha düşük olmuştur. Bu çalışma neticesinde BÇS'nin ısıl kütle etkisinin, yüksek hava sıcaklık değerlerinde, iç ortam sıcaklık değerlerini dengelediği belirlenmiştir.

Ekşi ve Uzun (2016, sny), çalışmalarında İstanbul Bahçeköy'de $24 \mathrm{~m}^{2}$ yüzey alanına sahip, \%1 eğimli teras çatısı olan prefabrike bir bina yapmışlardır. Bu çatının 10,2 $\mathrm{m}^{2}$ lik alanını tipik yüzeysel bitkilendirilmiş çatı, geri kalanını ise arduvaz mineralli bitümlü örtü ile kaplı referans çatı olarak tamamlamışlardır. Böylece İstanbul iklim şartlarında yer alan bir BÇS'nin, ISı yalıtımı, su tutma, yüzeysel akış, bitki büyüme durumu gibi özelliklerini ve çevresel etmenlerle olan etkileşimini belirlemek amacıyla referans bir çatı ile karşılaştırmalı ölçümler yapmışlardır. Çalışma sonucunda, BÇS'nin referans çatıya oranla bina içinde \%77 oranında ısı verimliliği sağladığı; yaz aylarında BÇS'de nem oranının azalması ile ısı yalıtım özelliğinin de azaldığı tespit edilmiştir. BÇS'nin, hava sıcaklığındaki değişimlerin döşemeye olan etkisini \%35-77 oranında azalttığı ve oldukça durağan bir sıcaklık dağılımı sağladığı ortaya konulmuştur. Bu çalışma sırasında BÇS yağış başladığı andan itibaren, yetişme ortamındaki su miktarına bağlı olarak yüzeysel akışa geçecek ya da çatıdan drenaj ortamına iletilecek su miktarını 1 ile 23 saat arasında geciktirdiği ve yüzeysel akışa geçen su miktarını \%20 - \%100 oranında azalttığı belirlenmiştir.

BÇS, yağmur suyunu bitki yetişme katmanında tutabilir; böylece yapıdan su toplama kanalına verilecek yağmur suyu miktarı azalır. "Büyük miktarda yağmur suyunu tutabilmeleri nedeniyle bitkilendirilmiş çatılar, kanalizasyona yağmur suyunun bağlandığı sistemlerde yoğun yağışlar sonucu olabilecek taşkınları ve kirliliği önleme potansiyeline sahiptir" (Miaomiao, 2011, 21). "BÇS, yağış suyundaki kirleticileri absorbe eder ve filtreler. BÇS'den uzaklaştırılan fazla su, yağmur hendeği ve su kanalları gibi çeşitli kontrol yöntemleri kullanılarak süzülür. Bu teknik kullanılarak Almanya'daki BÇS'li binaların yağmur suyu toplayan kanallar ile bağlantıları tamamen kesilmiştir" (Ngan, 2004, 3). Bu şekilde elde edilen yağmur suyu, bahçe sulama gibi gereksinimleri için kullanılabilir. 
BÇS, yüksek ve düşük hava sıcaklıklarında su yalıtım membranında genleşme ve büzülme sonucu görülebilecek hasarı önleyebilir. "Ottowa'daki Ulusal Araştırma Konseyi (National Research Council - NRC) tarafından yürütülen araştırma, 2001 yılının sıcak bir yaz gününde, $35^{\circ} \mathrm{C}$ 'lik bir hava sıcaklığında, referans çatının su yalıtım membranında sıcaklığın $70^{\circ} \mathrm{C}$ ye ulaştığını; BÇS'de bulunan su yalıtım membranının sıcaklığının ise, bitki yetişme katmanı sayesinde $25-30^{\circ} \mathrm{C}$ arasında kaldığını göstermektedir. Günlük sıcaklık dalgalanmalarının referans çatıda $46^{\circ} \mathrm{C}$, bitkilendirilmiş çatıda ise $6^{\circ} \mathrm{C}$ düştüğü bulunmuştur" (Ngan, 2004, 4).

"BÇS, doğal dış ortam ve iç ortam arasında sınır olmaları nedeniyle, karayolu, demiryolu ve hava trafiğinden kaynaklanan kentsel alanlardaki gürültü kirliliğini azaltır" (Yang ve ark. 2012, 44). Connelly ve Hodgson $(2013,1136)$ BÇS'lerin gürültü kirliliğinin azaltılmasına etkisini belirlemek amacıyla çeşitli bitki yetişme katmanı derinliği, bu katmanların su içeriği ve farklı bitki türlerini değişken olarak aldıkları bir çalışma yapmıştır. Bu çalışmanın sonucunda, BÇS'de gürültü iletim kaybının, bitki örtüsü olmayan referans çatılara göre düşük frekans aralığında $10 \mathrm{~dB}$; orta frekans aralığında ise 20 dB'e kadar azaldığını göstermiştir.

Vijayaraghavan, $(2016,743)$, Kent havasının, sık sık yüksek oranda insan sağlığı ve çevre için zararlı kirleticiler içerebildiğini ve BÇS kullanımının, kentsel hava kirliliğinin azaltılmasına yardım edebilecek popüler bir yaklaşım olduğunu söylemektedir. Yang ve arkadaşları (2008, 7266), BÇS'nin hava kirliliğine etkisi konusunda yaptıkları çalışmada bitkilerin doğrudan gözenekler yoluyla gaz halinde kirletici maddeleri tükettiği veya dolaylı olarak mikro iklimleri değiştirerek hava kirliliğini azalttığını söylemektedir. Dolaylı süreç, iç ortam ısıl konforu için enerji kullanımını azaltan ve kentsel ısı adası ile de ilişkili enerji tüketimiyle oluşan kirletici emisyonların bitkiler tarafından azaltılmasıdır. $\mathrm{Bu}$ çalışmada, 19,8 hektar bitkilendirilmiş çatı ile bir yılda, \% $52 \mathrm{O}_{3}, \% 27 \mathrm{NO}_{2}, \% 14 \mathrm{PM}_{10}$ ve $\% 7 \mathrm{SO}_{2}$ oranlarından oluşan toplam $1675 \mathrm{~kg}$ hava kirleticisinin temizlenebileceği belirlenmiştir.

Yüzeysel BÇS, genellikle kamusal erişime açık olmamaları nedeniyle mikroorganizmalar, böcekler ve kuşlar için bir yaşam alanı sağlayabilirler. "İsviçre'nin Basel kentindeki 17 yeşil çatının biyo çeşitliliği üzerine yürütülen çalışmada ilk 3 yıl boyunca 78 örümcek ve 254 böcek türü tespit edilmiştir. Bu örümceklerin yüzde 18'i ve böceklerin yüzde 11'i nesli tükenmekte olan veya nadir bulunan türlerdir" (Brenneisen, 2003, 328). Bazı araştırmacılar BÇS'ni, doğal bitki türlerini bir bölgeye tekrar kazandırıması için fırsat olarak değerlendirmektedir. Bu bağlamda Dewey ve arkadaşları (2004, 56), 35 yerel çim ve kır çiçeği türünü bitkilendirilmiş çatılar için değerlendirmiş, 21 türün sulama yapılan yoğun BÇS için, diğerlerinin sulama yapılmayan yüzeysel BÇS için uygun olduğunu tespit etmiştir.

Ayrıca BÇS'nin, kentsel görünüme estetik bir değer kazandırdığı, yoğun BÇS ile oluşan kamusal alanların kullanıcıların sosyalleşmesine katkıda bulunduğu da bilinmektedir.

Kentsel alanlardaki yoğun yapılaşmanın ısı adası oluşumuna etkisi göz önünde bulundurularak, bu çalışma kapsamında yoğunluğu yüksek yerleşim alanlarında BÇS'nin yaygınlaştırılması amaç olarak belirlenmiştir. 


\section{KAPSAM VE YÖNTEM}

Çalışma kapsamında, öncelikle BÇS'nin dünyada ve Türkiye'deki yaygınlık durumunun ve yaygınlaşmasının önündeki engellerin belirlenmesi için literatür taraması yapılmıştır. Literatür taraması neticesinde elde edilen BÇS'nin yaygınlaşmasının önündeki engellerin Türkiye'deki geçerliliklerini belirlemek amacıyla konuyla ilgili uzmanlar ile derinlemesine mülakat gerçekleştirilmiştir. Bu mülakatların sonuncunda elde edilen engellerin ağırlığını ve paydaşlara göre dağılımını belirlemeye yönelik bir anket çalışması hazırlanmıştır.

Binaların işlevi, çatı yüzeyi büyüklüğü, yerleşim alanı özellikleri gibi hususların BÇS uygulanması kararında etkili olduğu düşünülmektedir. Bu çalışmanın İstanbul kapsamında gerçekleşmesiyle, mülakatlarda yoğunluğu yüksek yerleşim alanları için BÇS'nin değerlendirmesi ortaya çıkmaktadır. Dolayısıyla, endüstriyel alan, kıyı yerleşimi, çatı yüzeyleri büyüklüğü toplamının kentsel dokuda seyrek yoğunluk oluşturduğu alanlar, kapsam dışında tutulmuştur. İstanbul, Türkiye genelinde yapı üretiminin en yoğun olduğu kentlerden biri olması nedeniyle bu araştırma için kapsam olarak seçilmiştir.

\subsection{Bitkilendirilmiş Çatı Sistemlerinin Dünyada ve Türkiye'de Yaygınlık Durumunun Değerlendirilmesi}

Çatıların bitkilendirilmesi antik dönemlere kadar uzanmaktadır. Shafique ve arkadaşları (2018, 759)'na göre, günümüzdeki anlamıyla bitkilendirilmiş çatılar ise, 1960'ların başında enerji krizinin yaşandığı Almanya'da, binalardaki enerji tüketimini azaltmak için inşa edilmeye başlanmıştır. 1980'lerin başında BÇS pazarı hızla genişlemiş ve Almanya'da birçok bitkilendirilmiş çatı inşa edilmiştir. 1982 yılında Almanya'da FLL (Forschungsgesellschaft Landschaftsentwicklung Landschaftsbau = Peyzaj Araştırma, Geliştirme ve Konstrüksiyon Topluluğu) BÇS yapımı için kılavuzlar yayınlamıştır. Bu kılavuz BÇS ile ilgili malzeme, detay ve uygulamaya yönelik bilgiler içeren ilk temel çalışmadır. Diğer Avrupa ülkeleri, Kuzey Amerika ve Japonya'nın BÇS konusunda hazırladıkları kılavuz ve yasal düzenlemelerde FLL'den yararlanılmıştır.

2005 ve 2006'da ASTM (American Standarts and Testing Materials- Amerikan Test ve Malzemeler Derneği) birliği tarafından bitkilendirilmiş çatı yapımının ayrıntılı olarak açıklandığı kılavuzların yayınlanması, bu konudaki önemli bir eksikliği İngilizce dilinde gidermiş ve BÇS uygulamalarının yaygınlaşmasına katkı sağlamıştır.

Türkiye'de önemli boyuttaki ilk bitkilendirilmiş çatı uygulaması, 1978 yılında Ankara MeSa Güneş Sitesi'nde yapılan uygulamadır (Kaymak, 2015, 67). Bu sistemler konusunda uzmanlaşmanın ve ticari uygulamaların başlangıcı ülkemizde doksanlı yılların ortalarına denk gelmektedir (Ekşi, 2014, 27). 1990'lı yılların sonu itibarıyla başlayıp günümüzde artarak süren kentsel ısı adası konusundaki araştırmalar BÇS'nin kentsel ıSı adasının azaltılmasına yönelik yararlarını da ortaya çıkarmaktadır. Ancak günümüz Türkiye'sinde BÇS uygulamalarına sosyal alan ve estetik değer üretme amacıyla genellikle alışveriş merkezlerinde, ofis ve karma yapılarda, toprak kotu altındaki otoparklarda sık olmamakla birlikte rastlanmaktadır.

BÇS'nin çevresel, sosyal ve ekonomik yararları nedeniyle farklı ülkelerde BÇS'nin yaygınlaşması amacıyla politikalar geliştirilmektedir. Bu politikalar genellikle BÇS'nin 
tercih edilmesini sağlamak amaçlı, yatırımcı ve kullanıcılara yönelik mali teşvik, su tüketimi ve mal bedelinde indirim gibi uygulamaları içermektedir. Berardi ve arkadaşları (2014, 425)'nın çalışmasından derlenen, farklı ülkelerdeki BÇS'nin yaygınlaşması için uygulanan teşvik politikaları Tablo 1'de yer almaktadır.

Tablo 1: BÇS uygulamalarının yaygınlaşması için farklı ülkelerde uygulanan politikalar, (Berardi ve ark. 2014)'ten derlenmiştir.

\begin{tabular}{|c|c|}
\hline Ülke & BÇS uygulamalarının yaygınlaşması için teşvik politikaları \\
\hline \multirow{3}{*}{ Almanya } & Munich: Yüzey alanı $100 \mathrm{~m}^{2}$ den büyük teras çatılar için BÇS zorunludur. \\
\hline & Esslingen: BÇS maliyetinin \%50'si kullanıcılara ödenecektir. \\
\hline & Darmstadt: Kullanıcılara BÇS uygulamaları karşılığında 5000 €'ya kadar ödeme yapılır. \\
\hline Danimarka & $\begin{array}{l}\text { Copenhagen: Eğimi } 30^{\circ} \text { ye kadar olan tüm yeni kırma çatılarda bahçe düzenlemesi } \\
\text { zorunludur; bu tür binalarda BÇS uygulanmalıdır. }\end{array}$ \\
\hline \multirow{2}{*}{ Kanada } & 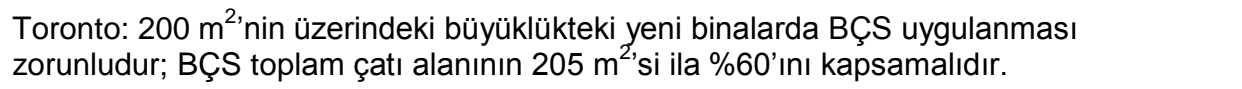 \\
\hline & $\begin{array}{l}\text { Vancouver, BC: } 5000 \mathrm{~m}^{2} \text { üzerindeki tüm ticari ve endüstriyel binalarda BÇS uygulanması } \\
\text { zorunludur; aksi halde bina sahibi ceza ödemek zorundadır. }\end{array}$ \\
\hline Singapur & $\begin{array}{l}\text { BÇS'nin kullanımı teşvik edilmekte ve kullanıcılar için bir Bina Toplam Taban Alanı teşvik } \\
\text { planı mevcuttur. }\end{array}$ \\
\hline Japonya & $\begin{array}{l}\text { Tokyo: } 1000 \mathrm{~m}^{2} \text { üzerindeki binalarda ve } 250 \mathrm{~m}^{2} \text { üzerindeki kamu binalarında BÇS } \\
\text { uygulanması zorunludur. Aksi halde bina sahibi yıllık ceza ödemek zorundadır. }\end{array}$ \\
\hline \multirow{10}{*}{ ABD } & $\begin{array}{l}\text { Chicago, IL: çatı alanının \%50 veya daha fazlasını kapsayan BÇS uygulamalarının } \\
\text { geliştirilmesi için maliyetin } \% 50 \text { 'sine kadar karşılanmakta ya da } 100.000 \$ \text { ödenmektedir. }\end{array}$ \\
\hline & $\begin{array}{l}\text { Portland, OR: yerel yönetim, imar kanununa uygun olarak emsal değeri üzerinden teşvik } \\
\text { vermektedir. (Ek izne gerek olmadan fazladan, her BÇS } \mathrm{ft}^{2} \text { için } 3 \mathrm{ft}^{2} \text { fazladan inşaat alanı } \\
\text { izni) }\end{array}$ \\
\hline & $\begin{array}{l}\text { Seattle, WA: Yerel yönetim, emsal değeri üzerinden teşvik olarak her BÇS } \mathrm{ft}^{2} \text { için } 3 \mathrm{ft}^{2} \\
\text { fazladan inşaat alanı izni vermektedir. }\end{array}$ \\
\hline & $\begin{array}{l}\text { Washington, DC: Bölgede, uygulanan her BÇS için } \mathrm{ft}^{2} \text { başına yaklaşık } 5 \$ \text { fon sağlayan } \\
\text { BÇS indirim programı mevcuttur. }\end{array}$ \\
\hline & $\begin{array}{l}\text { New York City, NY: Çatı alanının } \% 50 \text { ve daha fazlasına BÇS uygulanan binaların } \\
\text { kullanıcıları } 100.000 \$ \text { 'a kadar veya } \mathrm{ft}^{2} \text { başına } 4,5 \$ \text { tutarında yıllık vergi indirimi alabilir. }\end{array}$ \\
\hline & $\begin{array}{l}\text { Philadelphia, PA: Eyalet Yönetimi, BÇS uygulanmasına yapılan harcamaların \%25'ini } \\
\text { (100.000 \$ 'a kadar) Ticari Ayrıcalık Vergisinde indirim olarak sunmaktadır. }\end{array}$ \\
\hline & $\begin{array}{l}\text { Baltimore, MA: Eyalet Yönetimi, yağmur suyu toplanması/yönetimi için yapılan } \\
\text { harcamaların \%10'unu (en fazla } 10.000 \$ \text { ) yağmur suyu yönetimi vergisinde indirim } \\
\text { olarak sunmaktadır. }\end{array}$ \\
\hline & $\begin{array}{l}\text { Minneapolis, MN: BÇS uygulanan binaların kullanıcıları, yağış suyu yönetimi vergilerinde } \\
\% 50 \text { indirim alabilirler }\end{array}$ \\
\hline & $\begin{array}{l}\text { Nashville, TN: Kanalizasyon vergilerinde, uygulanan BÇS'nin her } \mathrm{ft}^{2} \text { si için } 10 \text { dolarlık bir } \\
\text { indirim sağlanmaktadır. }\end{array}$ \\
\hline & $\begin{array}{l}\text { Austin, TX: "Green Roof Density Bonus" (BÇS yoğunluk artışı) düzenlemesi ile, } 1 \mathrm{sq} / \mathrm{ft} \\
\text { BÇS için } 8 \mathrm{sq} / \mathrm{ft} \text { 'e kadar yoğunluk artışı verir. }\end{array}$ \\
\hline
\end{tabular}




\subsection{BÇS'nin Yaygınlaşmasının Önündeki Engellere İlişkin Bilgi Toplama}

Li ve Yeung'un (2014, 132), mevcut binalarda yüzeysel BÇS uygulamalarının yaygınlaşamama nedenleri üzerine yaptıkları literatür taraması Tablo 2'de özetlenmiştir.

Tablo 2: Mevcut binalarda BÇS uygulamalarının yaygınlaşamama nedenleri, (Li ve Yeung, 2014)'dan derlenmiştir.

\begin{tabular}{|c|c|}
\hline Yaygınlaşmasını Engelleyen Nedenler & Kaynaklar \\
\hline Bakım maliyetlerinin artması & $\begin{array}{l}\text { Peck ve Callaghan }(1999,45) \\
\text { Ngan }(2004,6)\end{array}$ \\
\hline Tasarım ve yapım maliyetlerinin artması & Ngan $(2004,6)$ \\
\hline Devletten yatırımcı ve iş geliştiricilere yönelik teşvik eksikliği & Getter ve Rowe $(2006,270)$ \\
\hline Devletten, (mevcut) binaların sahiplerine yönelik teşvik eksikliği & $\begin{array}{l}\text { Peck ve Callaghan }(1999,44) ; \\
\text { Getter and Rowe (2006) }\end{array}$ \\
\hline Tasarım ve yapım aşamalarındaki teknik zorluklar & $\begin{array}{l}\text { Peck ve Callaghan }(1999,49) \\
\text { Getter ve Rowe }(2006)\end{array}$ \\
\hline Binaların eski olması & Townshend $(2007,89)$ \\
\hline $\begin{array}{l}\text { Yüzeysel bitkilendirilmiş çatının rüzgar yüküne dayanıklılığının } \\
\text { finansal olarak karşılığı }\end{array}$ & $\begin{array}{l}\text { Peck ve Callaghan }(1999,46) \\
\text { Townshend }(2007,67)\end{array}$ \\
\hline $\begin{array}{l}\text { Yüzeysel bitkilendirilmiş çatı sistemi uygulamak için yapısal taşıyıcı } \\
\text { elemanların yetersizliği }\end{array}$ & Townshend $(2007,90)$ \\
\hline $\begin{array}{l}\text { Bitkilendirilmiş çatı sisteminin yüzey alanında düzenlemenin yetersiz/ } \\
\text { uygunsuz yapılması }\end{array}$ & Townshend $(2007,89)$ \\
\hline $\begin{array}{l}\text { Kamu ve özel sektörde yüzeysel bitkilendirilmiş çatı sistemi hakkında } \\
\text { farkındalık eksikliği }\end{array}$ & Hui $(2006,7)$ \\
\hline $\begin{array}{l}\text { Devlet ve sivil toplum örgütlerinde kamu ve özel sektöre tanıtımın } \\
\text { eksikliği /yetersizliği }\end{array}$ & Townshend $(2007,93)$ \\
\hline
\end{tabular}

Bruderman ve Sangkakool (2017, 232) çalışmalarında, Avrupa'nın ılıman iklimdeki şehirlerinde bitkilendirilmiş çatı teknolojisinin yaygınlaşması ile ilgili temel etkenleri belirlemeyi ve değerlendirmeyi amaçlamıştır. Bu amaçla, Avusturya'da 5 farklı uzmanlık alanında bitkilendirilmiş çatı konusunda çalışan 15 kişi ile yapılan görüşmeler neticesinde bitkilendirilmiş çatı teknolojisinin yaygınlaşması ile ilgili temel etkenler belirlenmiştir. Bu etkenler önce SWOT analizi ile sonra bir Analitik Hiyerarşi Süreci (AHP) kullanılarak değerlendirilmiş; sonuç olarak, BÇS'nin yayılma potansiyelinin olduğu saptanmıştır. Ancak, kamunun bitkilendirilmiş çatının avantajlarını yaşarken, risk ve potansiyel dezavantajların ise bina sahipleri tarafından yüklenilmesinin yanı sıra teşvikler konusunda çelişkiler bulunması, BÇS'nin Avusturya'da yaygınlaşmasının önündeki engeller olarak tespit edilmiştir.

Sangkakool ve ark. (2018, 408), Tayland'da BÇS'nin çevresel olumlu etkilerinin bilinmesine karşın, bu sistemlerin yaygınlaşamama nedenlerini ve bu nedenlerin etki 
değerlerini belirlemek amacıyla bir çalışma yürütmüşlerdir. Belirlenen nedenler nitel içerik analizi ile tanımlanmıştır. Olumlu ve olumsuz etkiler nitel olarak değerlendirildikten sonra Analitik Hiyerarşi Sürecinde nicel olarak değerlendirilmiştir. Bu araştırma, Tayland'da BÇS'nin yaygınlaşmasında en önemli etkenin, BÇS'nin kentsel ısı adalarını azaltma potansiyeli olduğunu ortaya koymuştur. Ancak finansal yardım (sübvansiyon) programlarının olmayışı, BÇS üretimi için yeterli nitelikte işgücünün olmayışı, BÇS’nin yaygınlaşmasının önündeki temel engeller olduğunu ortaya koymaktadır.

Chen ve ark. (2019, 748), Çin'de bitkilendirilmiş çatı sistemlerinin yaygınlaşamama nedenlerini 5 başlık altında toplamışlardır. Bu 5 başlık altında toplam 27 soru hazırlamışlardır. Her bir başlık kapsamında ilgili olan sorular gruplandırılmıştır. Yapı üretiminin 4 farklı sürecinde yer alan paydaşların ilgili olacakları başlıklar seçilerek, paydaşlara ilgili olacakları başlıklara göre gruplandırılan sorular yönlendirilmiştir. Yapılan anket çalışmasıyla toplamda 112 paydaşın görüşü alınmıştır. Anket sonuçlarının analizinde, BÇS'nin yaygınlaşmasındaki en etkili engeller: bakım maliyeti, tasarım ve yapım maliyeti, bitkilendirilmiş çatının yetersiz teknik ve işçilikle düzenlenmesi, iş geliştiricilere yönelik teşvik yetersizliği olarak belirlenmiştir.

\section{3. Çalışmanın Türkiye'deki Yapı Üretim Organizasyonu İle İlişkilendirilmesi}

Farklı ülkelerde BÇS'nin yaygınlaşması değerlendirilirken, yapı sektörü örgütlenme modelleri etkili olabilmektedir. Bu bağlamda, Türkiye'deki yapı sektörü paydaşlarının ve bu paydaşların BÇS üretimindeki etkinliklerinin tanımlanmasına gerek görülmüştür.

BÇS tasarımı ve uygulanması ve kullanımı süreçleri "peyzaj konsept projenin hazırlanması", "peyzaj uygulama projesinin hazırlanması", "uygulama", "uygulama danışmanlığı/ denetleme", "işletme ve bakım", "kullanım" şeklinde 6 aşamalı olarak ele alınabilir. Bu aşamalar, paydaşların etkinliğine göre üç temel grupta ele alınmıştır: "proje geliştirme/tasarım", "uygulama/denetleme" ve "kullanım/işletme/bakım" (Şekil 1).

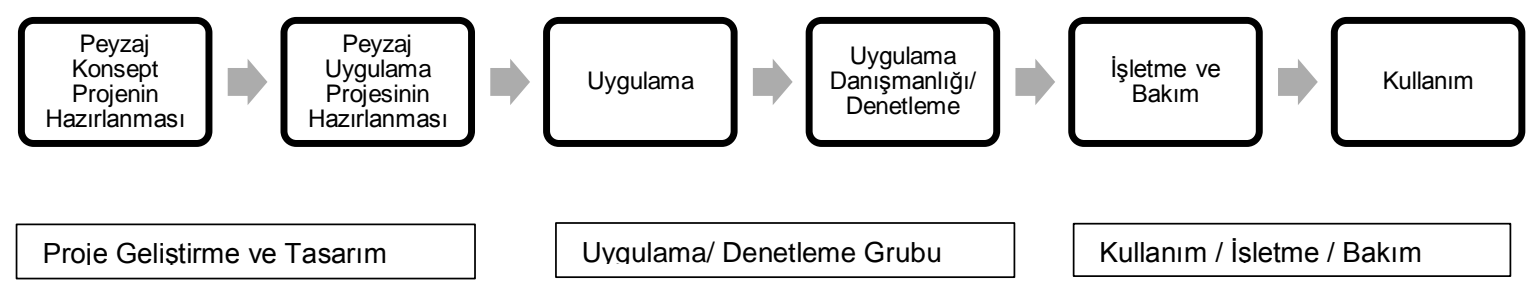

Şekil 1: BÇS tasarımı ve uygulanması ve kullanımı süreçleri

Türkiye yapı sektöründeki organizasyon biçimleri, farklı şartlarda değişkenlikler arz etmekte ve fiili durumda birbirinden çok farklı üretim ilişkileri ortaya çıkabilmektedir. Bu süreçlerde görev alan uzmanların etkinliklerini belirlemek amacıyla, 8 farklı paydaş tanımlanmıştır. Nihai kullanıcıların da, bina ömrü değerlendirildiğinde etkili olmaları nedeniyle, paydaş sayısı 9'a çıkmıştır. Bu paydaşların tasarım, uygulama ve işletme süreçlerinde görülen değişken organizasyon biçimlerine göre etkinlikleri farklılık gösterebilmektedir. Tablo 3'te, 9 farklı paydaşın, bina üretimi ve kullanımı süreçlerinde hangi aşamalarda yer alabilmesinin mümkün olabildiğini göstermektedir. 
Tablo 3: BÇS'nin tasarım, yapım ve işletme/ bakım süreçlerinde yapı sektörü paydaşlarının etkinlikleri

\begin{tabular}{|c|c|c|c|c|c|c|c|c|c|c|}
\hline & \multicolumn{9}{|c|}{ Paydaşlar } \\
\hline & & 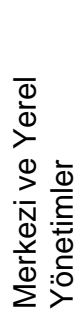 & 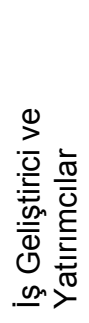 & 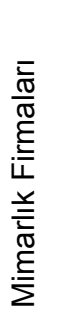 & 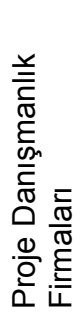 & 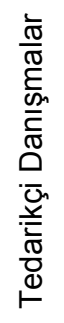 & 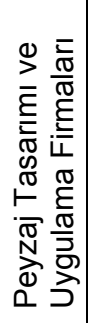 & 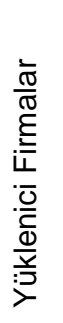 & 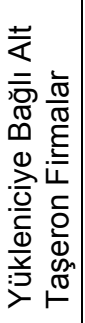 & $\begin{array}{l}\frac{\bar{O}}{\bar{E}} \\
\frac{\bar{D}}{\overline{\bar{V}}} \\
\overline{\underline{D}} \\
\frac{\bar{D}}{\bar{Z}}\end{array}$ \\
\hline \multirow{2}{*}{$\begin{array}{l}\text { Proje Geliştirme } \\
\text { ve Tasarım } \\
\text { Grubu }\end{array}$} & $\begin{array}{l}\text { Peyzaj Konsept } \\
\text { Projenin } \\
\text { Hazırlanması }\end{array}$ & * & * & * & & & & * & & \\
\hline & $\begin{array}{l}\text { Peyzaj Uygulama } \\
\text { Projesinin } \\
\text { Hazırlanması }\end{array}$ & * & & * & * & * & * & * & & \\
\hline \multirow[b]{2}{*}{$\begin{array}{l}\text { Uygulama/ } \\
\text { Denetleme } \\
\text { Grubu }\end{array}$} & Uygulama & & & & & & * & * & * & \\
\hline & $\begin{array}{l}\text { Uygulama } \\
\text { Danışmanlığı/ } \\
\text { Denetleme }\end{array}$ & * & * & * & * & * & * & & & \\
\hline \multirow{2}{*}{$\begin{array}{l}\text { Kullanım/ } \\
\text { İşletme/ Bakım } \\
\text { Grubu }\end{array}$} & İşletme ve Bakım & & * & & & & & * & & * \\
\hline & Kullanım & & * & & & & & & & * \\
\hline
\end{tabular}

Türkiye'de mimari firmalarının etkinliğine göre bina üretimi organizasyonunun şekillenişi, avan proje üretimi ile başlamaktadır. Mimarlık firmalarının etkinliğinin avan projesi ile sınırlı olması, uygulama projesini üstlenmesi ya da denetimde de söz sahibi olmasına göre, yapı üretimi organizasyon şemasında farklııklar ortaya çıkabilmektedir. Ancak mimari firmaların avan proje üretildikten sonra sürece dahil olamamaları durumunda, uygulama ve/veya denetim, proje danışmanlık firmalarına devredilebilmektedir. Proje danışmanlık firmaları daha çok işveren ve yüklenici ile birlikte süreçte rol almaktadır. Mimarını kendi bünyesinde çalıştıran yüklenici firmalar, avan proje ve uygulama projelerini yüklenici firma bünyesinde gerçekleştirmektedir. Bu tür oluşumlarda proje danışmanlığına da gerek görülmeden kimi zaman alt taşeronlarla inşaat süreci yürütülebilmektedir.

Türkiye'de BÇS yapılması kararı, çoğunlukla projenin tasarımı aşamasında, işveren/mal sahibi ve mimar tarafından birlikte alınmaktadır. BÇS tasarımı, genellikle mimari avan projenin hazırlanmasının ardından BÇS için konsept niteliğinde peyzaj projesinin hazırlanması ile başlamaktadır. BÇS için bir peyzaj mimarından yardım alma kararı, mimarın vizyonuna bağlıdır.

\subsection{Mülakat ve Anketlerin Hazırlanması}

Literatür taramasında belirlenmiş olan BÇS'nin yaygınlaşmasının önündeki engellerin Türkiye'deki geçerlilikleri, BÇS alanında uzman olan yapı sektörü paydaşları ile derinlemesine mülakatlar yapılarak değerlendirilmiştir. Bu değerlendirmeler sonucunda hazırlanan anket ile engellerin paydaşlara göre dağılımı ve birbirlerine göre önemi (ağırlığı) saptanmaya çalışılmıştır. Derinlemesine mülakat ve anket yöntemleri kullanılarak, yoğunluğu yüksek yerleşim alanlarında BÇS'nin yaygınlaşmasının 
önündeki engellerin ağırlıkları saptanmaya çalışılmıştır. Bu ağırlıkların saptanmasıyla BÇS'nin yaygınlaşmasının önündeki engellerin kaldırılmasına yönelik daha bilinç ve planlı adımların atılmasına olanak sağlanacaktır.

Araştırmanın mülakat aşamasında BÇS'nin Türkiye'de yaygınlaşamamasının önündeki engeller üzerine, Tablo 4'te yer alan, iş geliştirici, mimar, peyzaj mimarı, danışman, tedarikçi, uygulamacı ve denetçi olmak üzere 8 paydaş grubun her birinden 2 uzman ile yüz yüze görüşülerek toplamda 16 mülakat gerçekleştirilmiştir. Mülakatlar neticesinde belirlenen engeller "teknik ve teknolojik engeller", "Standart ve Yasal Düzenleme Eksikliğinden Kaynaklanan Engeller", "Maliyet Engeli", "Önyargılardan Kaynaklanan Engeller", "Teşvik Eksikliğinden Kaynaklanan Engeller" olmak üzere 5 grupta toplanmıştır (Tablo 4-5-6-7-8).

Tablo 4: BÇS uygulamalarında teknik ve teknolojik engeller

\begin{tabular}{|l|l|}
\hline $\mathrm{E}_{\mathrm{T} 1}$ & $\begin{array}{l}\text { BÇS'nin uygulanma sürecinde drenaj ve yalıtım gibi iş kalemlerindeki teknik zorluklar BÇS'nin } \\
\text { yaygınlaşmasında engel midir? }\end{array}$ \\
\hline $\mathrm{E}_{\mathrm{T} 2}$ & BÇS'nin bina taşıyıcı sistemine ek yük getirmesi BÇS'nin yaygınlaşmasında engel midir? \\
\hline $\mathrm{E}_{\mathrm{T} 3}$ & $\begin{array}{l}\text { BÇS'de uygulanan bitki örtüsünün seçiminde zorluk yaşanması } \\
\text { midir? }\end{array}$ \\
\hline $\mathrm{E}_{\mathrm{T} 4}$ & BÇS için sulama sisteminin yereksinimi BÇS'nin yaygınlaşmasısında engel midir? \\
\hline $\mathrm{E}_{\mathrm{T} 5}$ & $\begin{array}{l}\text { BÇS ile toplanabilecek yağmur suyu için toplama ve depolama sistemlerinin gerekliliği, BÇS'nin } \\
\text { yaygınlaşmasında engel midir? }\end{array}$ \\
\hline $\mathrm{E}_{\mathrm{T} 6}$ & $\begin{array}{l}\text { İnşaat teknolojileri, yapı malzemeleri ve malzeme testlerindeki yeterli gelişimin sağlanamaması } \\
\text { durumu BÇS'nin yaygınlaşmasında engel midir? }\end{array}$ \\
\hline $\mathrm{E}_{\mathrm{T} 7}$ & BÇS konusundaki bilgi ve deneyim eksikliği, BÇS'nin yaygınlaşmasında engel midir? \\
\hline
\end{tabular}

Tablo 5: BÇS uygulamalarında standart ve yasal düzenlemelerin eksikliğinden kaynaklanan engeller

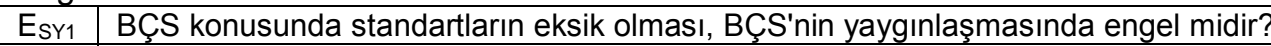

ESY2 BÇS konusunda yasal düzenlemelerin eksik olması, BÇS'nin yaygınlaşmasında engel midir?

Tablo 6: BÇS uygulamalarında maliyetten kaynaklanan engeller

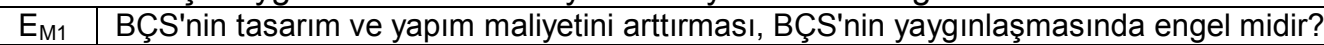

$\mathrm{E}_{\mathrm{M} 2}$ BÇS'nin bakım ve işletme maliyetini arttırması, BÇS'nin yaygınlaşmasında engel midir?

$\mathrm{E}_{\mathrm{M} 3} \quad \mathrm{BÇS'nin} \mathrm{mülkün} \mathrm{satın} \mathrm{alma} \mathrm{maliyetini} \mathrm{yükseltmesi,} \mathrm{BÇS'nin} \mathrm{yaygınlaşmasında} \mathrm{engel} \mathrm{midir?}$

Tablo 7: BÇS uygulamalarında önyargılardan kaynaklanan engeller

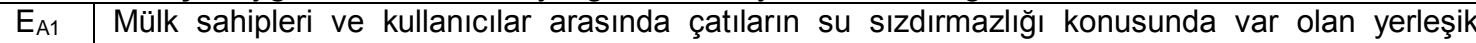
endişeler, BÇS'nin yaygınlaşmasında engel midir?

EA2 Kullanıcıların, çatıların bitkilendirilmesi konusunda yeterince istekli olmaması, BÇS'nin yayg ınlaşmasında engel midir?

EA3 BÇS detaylarının tasarım süreçlerinde göz önüne alınmıyor olmasından kaynaklı, kullanım sürecinde ortaya çıkan maliyetli tecrübelerin yanlış yargılar oluşturması, BÇS'nin yaygınlaşmasında engel midir?

E $E_{\mathrm{A} 4} \quad$ Mülk sahipleri ve geliştiricileri arasında BÇS'nin yatııı ve bakım maliyetlerini artırması konusunda duyulan endişe, BÇS'nin yaygınlaşmasında engel midir?

Tablo 8: BÇS uygulamalarında teşvik eksikliğinden kaynaklanan engeller

$\mathrm{E}_{\mathrm{D} 1} \quad \mathrm{BÇS}$ uygulamaları konusunda merkezi ve yerel yönetimlerden bina sahiplerine yönelik teşviklerin eksikliği, BÇS'nin yaygınlaşmasında engel midir?

ED2 $\quad$ BÇS uygulamaları konusunda merkezi ve yerel yönetimlerden yatırımcı ve proje geliştiricilere yönelik teşviklerin eksikliği, BÇS'nin yaygınlaşmasında engel midir?

Ankette, 5 engel grubunda toplam 18 soru yer almıştır. Yanıtlar için beşli değerlendirme skalası düzenlenmiştir. Yanıtlar "engel değil"=1 puan, "zayıf engel"=2 puan, "orta engel"=3 puan, "engel" $=4$ puan, "çok engel" $=5$ puan olarak düzenlenmiştir. Anket 
sonucunda en yüksek puanı alan engel, olumsuzluğu en güçlü engel olacaktır. Anketlerde paydaş gruplarının değerlendirdikleri engel grupları, paydaşların faaliyet alanlarına göre farklı olacak şekilde tasarlanmıştır. Yapılan anket sayısının, bina ömrü süreçlerine göre tanımlanmış paydaş gruplarına dağılımı ve değerlendirdikleri engel grupları Tablo 9'da gösterilmiştir.

Tablo 9: Anket yapılan paydaş grupları, soru olarak yöneltilen engel türleri ve yanıtların dağı̆ımı

\begin{tabular}{|c|c|c|c|c|c|c|}
\hline \multirow[b]{2}{*}{ Paydaş Grupları } & \multirow[b]{2}{*}{$\begin{array}{l}\text { Yapılan } \\
\text { Anket } \\
\text { Sayısı }\end{array}$} & \multicolumn{5}{|c|}{ Paydaşlar tarafından değerlendirilen engel grupları } \\
\hline & & 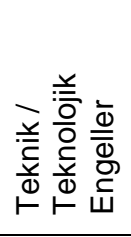 & 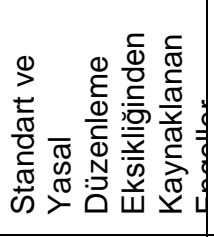 & 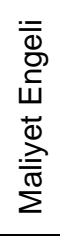 & 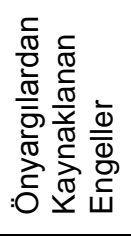 & 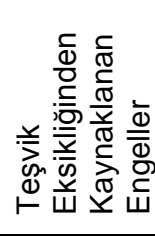 \\
\hline Proje Geliştirme ve Tasarım Grubu & 20 & * & * & * & * & * \\
\hline Uygulama/ Denetleme Grubu & 20 & * & * & & & \\
\hline Kullanım/ İşletme/ Bakım Grubu & 7 & & & * & * & * \\
\hline Uygulanan toplam anket sayısı : & 47 & 40 & 40 & 27 & 27 & 27 \\
\hline
\end{tabular}

\section{VERi ANALizi}

Anket çalışmaları yüz yüze görüşme ve e-posta yolu ile yürütülmüş ve \%100 oranında geri dönüş sağlandı. Katılımcıların seçiminde BÇS konusunda deneyimli olmasına dikkat edildi. Yapılan anket sonucunda elde edilen veriler kullanılarak her bir engel için olasılık kütle fonksiyonları elde edilmiş ve bu fonksiyon kullanılarak her bir engel için istatistiksel ortalama hesaplanmıştır. Bu ortalama puanlar üzerinden hangi engelin gerek paydaş grubu içinde ve gerekse tüm paydaşların oluşturduğun büyük grup içinde en yüksek etkiye sahip olduğu değerlendirilmiştir. Kütle fonksiyonunu $\mathrm{p}_{\mathrm{X}}(\mathrm{x})$, elde etmek için her bir engel için verilen puanlar değer olarak alınmış ve bu değerlerin ortaya çıkma olasılıkları her bir puanı puanlayan katılımcı sayısının toplam katılımcı sayısına oranlanmasıyla normalize edilerek bulunmuştur. Böylece değer uzayında her bir değere bir kütle değeri karşılık düşürülmüştür. Buna göre elde edilen kütle fonksiyon grafikler aşağıdaki gibi elde edilmiştir.

Elde edilen her bir kütle fonksiyonu $\mathrm{p}_{\mathrm{X}}\left(\mathrm{x}_{\mathrm{i}}\right)$ kullanılarak ortalama;

ve standart sapma;

$$
\mu=\mathrm{E}(\mathrm{x})=\sum_{\mathrm{i}=1}^{5} \mathrm{x}_{\mathrm{i}} \mathrm{p}_{\mathrm{X}}\left(\mathrm{x}_{\mathrm{i}}\right)
$$

$$
\sigma=\sqrt{\sum_{i=1}^{5}\left(x_{i}-\mu\right)^{2} p_{X}\left(x_{i}\right)}
$$

olarak hesaplanmıştır.

Engeller, ortalama puanlarının büyüklüğüne göre Tablo 10 'da sıralanmıştır. Ortalama puanı eşit olan engellerin sıralamasında standart sapma değeri küçük olan daha üst sıraya yerleştirilmiştir. "BÇS uygulamaları konusunda merkezi ve yerel yönetimlerden 
bina sahiplerine yönelik teşviklerin eksikliği” $\left(E_{D 1}\right)$ Türkiye'deki BÇS'nin yaygınlaşmasının önündeki engel olarak ilk sıradadır (Şekil 2).

Anket sonuçları paydaş grupları için ayrı ayrı değerlendirildiğinde, birincil önemde olan engellerin farklııı gösterdiği ortaya çıkmıştır. Buna göre, Proje Geliştirme ve Tasarım Grubu için birincil engel: "Mülk sahipleri ve geliştiricileri arasında BÇS'nin yatırım ve bakım maliyetlerini artırması konusunda duyulan endişe" ( $\left.E_{\mathrm{A} 4}\right)$ olarak belirlenmiştir. Uygulama/ Denetleme Grubu için birincil engel: "BÇS konusunda standartların eksik olması", ( $\left.E_{S Y 1}\right)$ olarak belirlenmiştir. Kullanım/ İşletme/ Bakım Grubu için birincil engel: "BÇS uygulamaları konusunda merkezi ve yerel yönetimlerden bina sahiplerine yönelik teşviklerin eksikliği, $\left(E_{D 1}\right)$ olarak belirlenmiştir.

Tablo 10: Engellerin ortalama puan değerlerine göre sıralanması

\begin{tabular}{|c|c|c|c|c|}
\hline Sıralama & Engel & $\begin{array}{c}\text { Engeli } \\
\text { değerlendiren } \\
\text { katılımcı sayısı }\end{array}$ & $\begin{array}{c}\text { Ortalama } \\
\text { puan } \\
(\mu)\end{array}$ & $\begin{array}{c}\text { Standart } \\
\text { sapma } \\
(\sigma)\end{array}$ \\
\hline 1 & $\mathrm{E}_{\mathrm{D} 1}$ & 40 & 4,185 & 1,644 \\
\hline 2 & $\mathrm{E}_{\mathrm{A} 4}$ & 27 & 4,074 & 1,538 \\
\hline 3 & $\mathrm{E}_{\mathrm{A} 2}$ & 27 & 4,074 & 1,657 \\
\hline 4 & $\mathrm{E}_{\mathrm{D} 2}$ & 27 & 4,037 & 1,411 \\
\hline 5 & $\mathrm{E}_{\mathrm{A} 3}$ & 27 & 4,037 & 1,625 \\
\hline 6 & $\mathrm{E}_{\mathrm{SY} 1}$ & 40 & 4,025 & 1,495 \\
\hline 7 & $\mathrm{E}_{\mathrm{SY} 2}$ & 40 & 3,900 & 1,939 \\
\hline 8 & $\mathrm{E}_{\mathrm{A} 1}$ & 27 & 3,851 & 1,893 \\
\hline 9 & $\mathrm{E}_{\mathrm{M} 1}$ & 27 & 3,814 & 1,940 \\
\hline 10 & $\mathrm{E}_{\mathrm{T} 7}$ & 40 & 3,800 & 2,028 \\
\hline 11 & $\mathrm{E}_{\mathrm{M} 2}$ & 27 & 3,777 & 2,012 \\
\hline 12 & $\mathrm{E}_{\mathrm{T} 1}$ & 40 & 3,350 & 2,191 \\
\hline 13 & $\mathrm{E}_{\mathrm{T} 4}$ & 40 & 3,125 & 2,082 \\
\hline 14 & $\mathrm{E}_{\mathrm{M} 3}$ & 27 & 3,111 & 1,872 \\
\hline 15 & $\mathrm{E}_{\mathrm{T} 6}$ & 40 & 3,025 & 2,092 \\
\hline 16 & $\mathrm{E}_{\mathrm{T} 2}$ & 40 & 2,875 & 2,036 \\
\hline 17 & $\mathrm{E}_{\mathrm{T} 3}$ & 40 & 2,800 & 2,335 \\
\hline 18 & $\mathrm{E}_{\mathrm{T} 5}$ & 40 & 2,625 & 1,964 \\
\hline
\end{tabular}

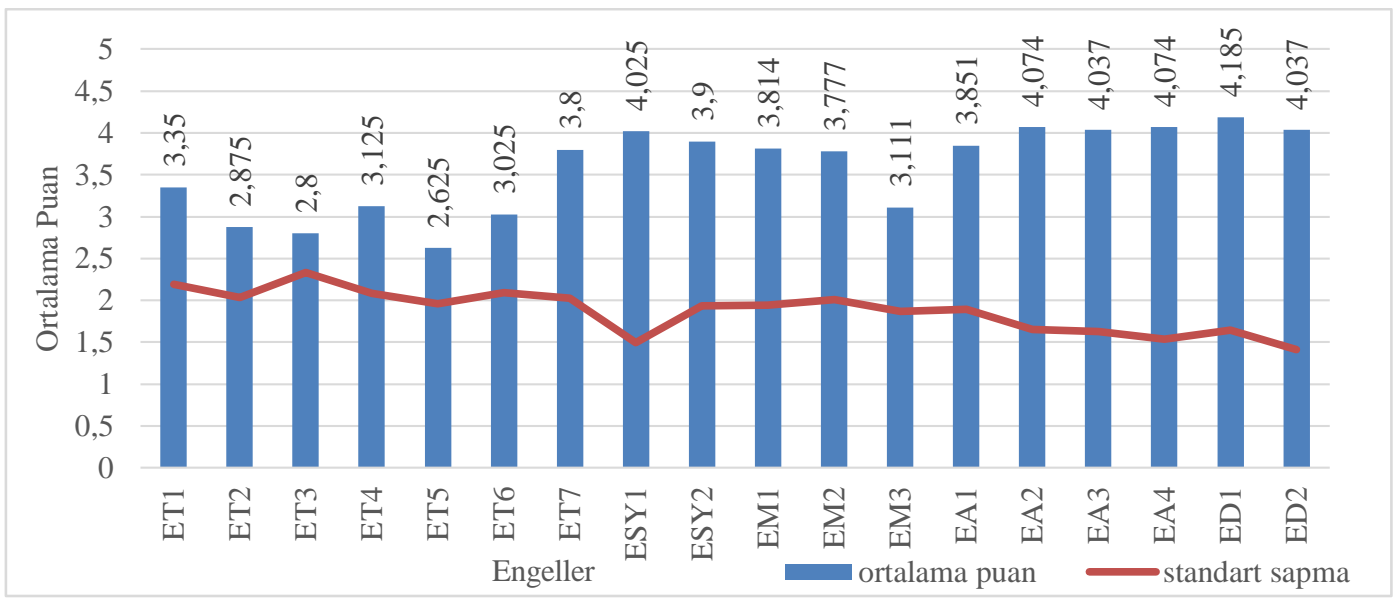

Şekil 2: Anket sonucunda engellerin ortalama puan değerleri; 


\section{TARTIŞMA}

Bu araştırmanın bulguları "Teşvik Eksikliğinden Kaynaklanan Engeller", "Önyargılardan Kaynaklanan Engeller" "Standart ve Yasal Düzenleme Eksikliğinden Kaynaklanan Engeller", "Maliyet Engeli", "Teknik ve Teknolojik Engeller", olmak üzere 5 başlık alında ele alınmıştır. Bu başlıklar, Tablo 10'da yer alan puanlamaya göre sıralanmıştır.

\subsection{Teşvik Eksikliğinden Kaynaklanan Engeller}

Görüşülen ve ankete katılan tüm paydaşların "BÇS uygulamaları konusunda merkezi ve yerel yönetimlerden bina sahiplerine yönelik teşviklerin eksikliği" ni $\left(E_{D 1}\right)$, birincil önemde engel olarak gördüğü ortaya çıkmıştır. BÇS'nin ekolojik ve sosyal bir çok yararları olmasına karşın, işletme ve bakım süreçlerinde ortaya çıkan maliyet mal sahibi ya da kiracı tarafından karşılanmaktadır. Yatırım amaçlı edinilen mülklerde kar amacı önem kazanırken, ekolojik unsurlar tamamen göz ardı edilmektedir. Bu tür mülklerin kiracıları ise işletme ve bakım maliyetlerindeki artışlar nedeniyle BÇS'ne mesafeli durmaktadır. İşletme ve bakım giderleri için mal sahibi ve kiracılara teşvik uygulanması, BÇS'nin yaygınlaşmasına katkı verecektir.

"BÇS uygulamaları konusunda merkezi ve yerel yönetimlerden yatırımcı ve proje geliştiricilere yönelik teşviklerin eksikliği” $\left(E_{D 2}\right)$ ise, dördüncü önemde engel belirlenmiştir. Bu engelle ilgili olarak, Bilim, Sanayi Ve Teknoloji Bakanlığı tarafından 2016 yılında "Araştırma, Geliştirme Ve Tasarım Faaliyetlerinin Desteklenmesine İlişkin Uygulama Ve Denetim Yönetmeliği” yayınlanmıştır. Bu yönetmelik kapsamında tasarım merkezlerinde gerçekleştirilen tasarım harcamaları nedeniyle gelir vergisinde indirim yapılması düzenlenmiştir. BÇS uygulamalarında tasarım grubu paydaşları tarafından değerlendirilebilecek bu vergi indirimi düzenlemesi, teknoloji merkezleri ve Ar-Ge merkezlerini de kapsaması nedeniyle, tasarım faaliyetinin değerlendirilmesi ve sürekliliği konusunda bina üretimine yönelik teşviklerin düzenlenmesi yararlı olacaktır.

\section{2. Önyargılardan Kaynaklanan Engeller}

Paydaşlarda görülen önyargıların, BÇS'nin yaygınlaşmasında önemli düzeyde engel olduğu anlaşılmaktadır. "Mülk sahipleri ve geliştiricileri arasında BÇS'nin yatırım ve bakım maliyetlerini artırması konusunda duyulan endişe" $\left(E_{A 4}\right)$, önyargı durumunda olmakla birlikte maliyetle ilişkilendirilebilecek bir engel olup, 2 . sırada yer almıştır.

Tablo 10'da, "Kullanıcıların, çatıların bitkilendirilmesi konusunda yeterince istekli olmaması" $\left(E_{\mathrm{A} 2}\right) 3$. sırada önemli engel olarak görülmektedir. Mülakat sürecinde görüşülen iş geliştirici ve yatırımcılar, nihai kullanıcının eğilimlerini belirlemek amacıyla düzenli anketler yaptırdıklarını ifade etmişlerdir. Bu anketlerde kullanıcıların bitkilendirilmiş dokuyu yapıların bünyesinde değil, özellikle yapı dışındaki bahçe kotunda çözümlenmiş, "açık bitkilendirilmiş alanlar" olarak tercih ettikleri yönünde bir eğilimin olduğu ortaya çıkmıştır. Dolayısıyla BÇS uygulamalarının, zemin üst kotundaki yapı kabuğuna kıyasla zemin altı otopark düzenlemelerinin çatı yüzeyinde daha yaygın kabul görmesi söz konusudur. Diğer yandan, kullanıcılar genellikle BÇS'ni, üzerinde gezilebilir, estetik görünümlü alan olarak kabul etmektedir. Ancak yoğun ya da yüzeysel gibi yapısal özellikleri nedeniyle BÇS her zaman bu kabule uymayabilir. Yüzeysel BÇS kullanımında seçilen bitkiler beklenilen estetik görünümü her zaman karşılayamayabilir; üzerinde dolaşım ve bu alanın kullanımı mümkün olmayabilir. 
Türkiye'deki çatı sistemleri uygulamalarında işçilik ve/veya detay kaynaklı ısı ve su yalıtımı sorunları ile sık karşılaşımaktadır. Bu nedenle, mal sahibi ya da kiracı olan nihai kullanıcılarda BÇS'nin sorun getirebilecek bir uygulama olmasına yönelik ciddi ön yargılar gözlemlenmiştir $\left(E_{A 3}\right)$. BÇS ile ilgili yaygın ön yargılar, bakımının zor olması, yapım maliyetini artırması, BÇS uygulanan çatının su sızdırması, yangın ya da aşırı rüzgâr durumlarında sorunların yaşanabilmesi, çeşitli haşere ve zararlıların üremesini kolaylaştırması gibi sıralanabilir. Nihai kullanıcının tutumunda belirlenen bu önyargılar, proje geliştirme ve tasarım grubu paydaşlarında BÇS üretimine yönelik girişimleri olumsuz etkilemektedir.

Merkezi ve yerel yönetimler tarafından kamu binalarında BÇS uygulanması ile kamu bilinci ve bu konuda talebin artması sağlanabilir. Merkezi ve yerel yönetimlerin geliştireceği politikalar ile, gerek uygulamada gerekse de işletme ve bakım süreçlerinde BÇS'nin yaygınlaşmasının önündeki engellerin azaltılması konusunda etkili olabilir.

\subsection{Standart ve Yasal Düzenleme Eksikliğinden Kaynaklanan Engeller}

Anket sonucunda standart ve yasal düzenleme eksikliğinden kaynaklanan engeller $\left(E_{S Y 1}\right)$ ve $\left(E_{S Y 2}\right) 6$ ve 7. sırada yer almıştır. Türkiye'de BÇS konusunda TSE (Türk Standartları Enstitüsü) föyleri taranmış ancak sonuçta BÇS ile doğrudan ilgili bir standart bulunamamıştır. BÇS ile doğrudan ilgili yasal düzenleme bağlamında, "Planlı Alanlar İmar Yönetmeliği", "İstanbul İmar Yönetmeliği" ve dolaylı ilgili olarak ise "İski Atıksuların Kanalizasyona Deşarj Yönetmeliği" değerlendirmiştir.

Planlı Alanlar İmar Yönetmeliği Madde 40/14'e göre: "Teras çatılarda çatı bahçesi olarak düzenleme yapılabilir. Bahçe düzenlemesi yapılabilmesi için gerekli olan 0.50 metre toprak dolgu, parapet yüksekliğine dâhil edilmez" (Planlı Alanlar İmar Yönetmeliği, 2017,17) ifadesi yer almaktadır. Bu yönetmelikte, BÇS'nin yapım koşulları ve özellikleri yer almakta; BÇS uygulanan binanın gabari kotuna, çatı kotundaki yapılaşma koşullarına dikkat çekilmektedir.

İstanbul İmar Yönetmeliği Madde 44/21' e göre: "Kamu binaları da dâhil olmak üzere yeni yapılacak toplam inşaat alanı $60.000 \mathrm{~m}^{2}$ üzerinde olan binalarda kent ekolojisini iyileştirmek, iklimsel klima etkisini kırmak, yağmur suyunu tutarak ani su baskınlarını azaltmak, inşaatların yeşil alan tahribini önlemek, nefes alınabilecek doğal bir ortam oluşturmak ve çatılarda ısı ve gürültü yalıtımını sağlamak amacıyla yeşil çatı sistemleri uygulanması zorunludur. Ayrıca toplam inşaat alanı $30.000 \mathrm{~m}^{2 \prime}$ den fazla olan binalarda teras çatı yapılmak istenmesi durumunda yeşil çatı sistemleri uygulaması yapılması zorunludur" (İstanbul İmar Yönetmeliği, 2018, 32). BÇS'nin yaygınlaşabilmesi için bina toplam inşaat alanının imar yönetmeliğinde belirtilen büyüklüğü, tek yapı ölçeğinde yüksek kalmaktadır. Yönetmelikte tanımlı inşaat alanından daha az inşaat alanına sahip, küçük ve orta ölçekli projelerin de BÇS uygulamasını teşvik edilmesi yararlı olacaktır. Diğer yandan toplam inşaat alanının tanımlı olması yanı sıra, binanın taban alanı ve yüksekliği ile ilişkili olarak çatı yüzeyinin büyüklüğüne dair tanımlamalar gereklidir. Bu bağlamda, merkezi ve yerel yönetimlerin 1/1000 uygulama imar planları hazırlarken parsel bazındaki yapım faaliyetlerini düzenlemesi, BÇS'nin yaygınlaşmasına, etkin ve verimli kullanılmasına katkı sağlayacaktır.

İstanbul İmar Yönetmeliği Madde 44/22'ye göre: "Binaya hizmet eden ortak alan olarak düzenlenecek yeşil çatı uygulamalarında; çim, bitki, çiçek ve küçük ağaç türlerinin 
yetiştirileceği en az 0.50 metre toprak dolgu oluşturulacaktır. Bina taşıyıcı sistemi toprak yükü de hesaplanarak çözülecek olup çatıda su ve ısı yalıtımı sağlanacaktır. Yapılacak olan toprak dolgu parapet yüksekliğine ilave edilmez" (İstanbul İmar Yönetmeliği, 2018, 32). İmar yönetmeliğindeki bu madde BÇS'nin karmaşıklığı düşünüldüğünde yaygın uygulamada yeterli olacak bir yönlendirme değildir. BÇS uygulamaları açısında bu dar çerçeve ele alınarak yapılan üretimlerde hatalı sonuçlar verme riski taşımaktadır.

İski Atık suların Kanalizasyona Deşarj Yönetmeliği Madde 6'ya göre: "Bölgede ayrık kanalizasyon sistemi mevcut ise; Yağmur suları ve kirli olmayan tüm diğer yüzeysel drenaj suları evsel atıksu kanallarına bağlanamaz". BÇS uygulamalarının yaygınlaşabilmeleri açısından yağmur sularının geri kazanımı hem işletme maliyetlerinde tasarruf sağlanması hem de azalan su kaynaklarının korunumu açılarından önemlidir. Ancak projelerde yağmur suyu geri kazanımının genellikle dikkate alınmadığını ortaya çıkmaktadır.

\subsection{Maliyet Engeli}

BÇS yapımının maliyeti, bitki yetiştirme ortamı, yalıtım membranın tipi, bitki miktarı ve drenaj sistemi bileşenlerine bağlıdır. Li ve Yeung, (2014, 132), EPA'nın 2009 yılında hazırladığı bir rapordan yararlanarak yüzeysel bitkilendirilmiş çatı ve yoğun bitkilendirilmiş çatı sistemlerinin ABD'deki maliyetlerini karşılaştırmışlardır. Bu rapora göre, yatırım maliyetleri basit bir yüzeysel BÇS için $\mathrm{m}^{2}$ başına 107,64 $\$$, yoğun BÇS ise $\mathrm{m}^{2}$ başına 270 olduğu tahmin edilmektedir. Türkiye'de geçerli BÇS birim maliyetinin belirlenmesi için, İstanbul inşaat piyasasında Temmuz 2019 tarihinde alınmış fiyatlar değerlendirilmiştir. Buna göre, yüzeysel BÇS için işçilik dahil $\mathrm{m}^{2}$ başına yaklaşık 169-224 TL; yoğun BÇS için işçilik dahil $\mathrm{m}^{2}$ başına yaklaşık 195-245 TL civarındadır. Bu bedeller Merkez Bankası'nın 2019 yılı Temmuz ayı ortalama döviz kuruna göre, yüzeysel çatı BÇS için yaklaşık 31-41 \$; yoğun BÇS için yaklaşık 35,50$44,50 \$$ aralığındadır.

"Uluslararası ölçekte, bina ömrüne yönelik maliyet tasarrufu, uygulama zorluğu olsa bile pratikte BÇS'nin yaygınlaşmasının gerisindeki en çekici faydalarındandır. Ancak Türkiye gibi gelişmekte olan ülkelerde, yaygın olarak kullanılan geleneksel ahşap çatılar göz önünde bulundurulduğunda, yaygın kanı olarak bitkilendirilmiş çatıların (green roofs) yüksek yatırım ve bakım maliyetleri gerektiriyor olmaları nedeniyle, tercih edilmeleri yönünde müşterilerin isteksiz oldukları gözlemlenmektedir" (Ulubeyli ve Arslan, 2017, 315).

Anket sonuçlarına göre 2. önemli engel olan "Mülk sahipleri ve geliştiricileri arasında BÇS'nin yatıım ve bakım maliyetlerini artırması konusunda duyulan endişe" $\left(E_{A 4}\right)$, maliyet engeli ile ilişkilendirilebilir. Bir binada BÇS olmaması, çatı bakım maliyetinin olmadığı anlamına gelmemektedir. Diğer yandan BÇS uygulamaları, BÇS'nin bakımı, peyzaj düzenlemesi, su tüketimi, ilaç ve gübre gibi gereksinimler ile bina bakım maliyetini artırmaktadır.

Yüzeysel bitkilendirilmiş veya yoğun bitkilendirilmiş çatılar için bakım maliyetleri $\mathrm{m}^{2}$ başına 8 ila 11 \$ arasındadır (Li ve Yeung, 2014, 132). Nihai kullanıcı bu masrafları karşılamak istemeyebilir. Bu durumda proje geliştiricilerin ve nihai kullanıcıların, BÇS 
uygulaması ile binanın kullanım sürecinde sağlanacak enerji ve su tasarrufunun yatırım maliyetinin karşılanmasındaki etkisi üzerine ikna edilmesi gerekmektedir.

Bakım maliyetinden farklı olarak tasarım ve yapım maliyeti bir defaya mahsustur. Bina tipolojisinden bağımsız olarak BÇS yapısal analiz, su geçirimsizlik ve drenaj, sulama tasarımı gibi konularda farklı teknoloji ve uzmanlık gerektirir. Bu hususlar yapım maliyetini artırır. Yapım maliyetin azaltılmasına yönelik alınabilecek kararlar ise, yerel malzeme ve bitki örtüsü kullanmak olabilir. Diğer yandan BÇS'nin yalnızca mülk sahiplerine değil, aynı zamanda kentsel çevreye de sağladığı yararlar göz önünde bulundurularak merkezi ve yerel yönetimler tarafından paydaşlara finansal teşvik ve indirimlerin uygulanması yararlı olacaktır.

\subsection{Teknik ve Teknolojik Engeller}

BÇS yapılması kararı, bina yapım süreçlerinin daha ileri aşamalarında da verilebilmektedir. Bu durumda taşıyıcı sisteme aktarılacak yük, bitki yetişme katmanının yüksekliği, yağış sularının tahliyesi için gerekli boruların yerleşimi gibi nedenler ile ciddi kısıtlılıklar ortaya çıkmaktadır. Mimarlık firmaları ve peyzaj tasarım ve uygulama firmaları ile yapılan mülakatlarda, Türkiye'de uygulanan BÇS'nin \%30'unun, mimaristatik tasarım süreçleri tamamlandıktan sonra BÇS yapılması kararı alınan projeler olduğunu çıkarımına varılmıştır. Statik tasarım sürecinden sonra BÇS yapılması kararının alındığı durumlarda, döşeme üzerinde yükseltilmiş saksılar ile bitkilendirme yapmak gibi "kısmi bitkilendirilmiş çatı" üretilebilmektedir. Ayrıca, tasarım sürecinde taşıyıCı sistemi BÇS'ne uygun olarak çözülmüş binalarda, uygulama süreçlerinde BÇS'den vazgeçilmesi de mümkün olabilmektedir. Bu durumun en önemli etkenleri ise, işletme ve bakım maliyetleri konusunda endişe duyulması, uygulama sürecinin hızlandırılması, iklimlendirme ve klima ünitelerinin teras çatıda çözümlenmesi gibi nedenlerdir.

Türkiye'de BÇS uygulamaları için malzeme üretimi, tedariki ve test teknolojilerinin yeterliliği konularında sorunlarla karşılaşılmamaktadır. Diğer yandan, Türkiye'deki BÇS uygulamalarında yaygın olarak ithal malzeme ve detay şablonlarının kullanılması sonucunda sorunlarla karşılaşılabilmektedir. İthal BÇS uygulama detaylarının iklim koşullarına uyarlanması, yerel bitki türleri ve uygun yetişme katmanı belirlenmesi gibi konuların araştırılması gerekliliğinin, Proje Geliştirme ve Tasarım Grubu paydaşları tarafından benimsenmediği anlaşılmaktadır.

Uzman teknik eleman eksikliği nedeniyle, işçilikten kaynaklı teknik hataların yarattığı uzun vadeli sorunlar, BÇS uygulamalarının yaygınlaşmasında önemli bir engel olmaktadır.

Mülakatlar irdelendiğinde, gri su kullanımının bazı durumlarda nihai kullanıcı tarafından güvenilir bulunmadığı; bazı durumlarda ise yanlış teknolojik uygulamalar ya da uygulama hataları nedeniyle kullanım sürecinde çeşitli sorunlara ve dolayısıyla maliyet artışlarına yol açabildiği anlaşılmaktadır.

\section{SONUÇ}

Bu çalışmada, Türkiye'de BÇS yaygınlaşmasının önündeki engeller, yapı sektörü paydaşları ile gerçekleştirilen derinlemesine mülakatlar ve anketler yapılarak araştırımıştır. Çalışmanın sonucunda teşviklerin yetersizliği, önyargılardan 
kaynaklanan engeller ve yasal düzenleme eksikliğinden kaynaklanan engellerin öne çıktığı saptanmıştır. Saptanan engellerin aşılabilmesi için önerilerde bulunulmuştur.

Yapı sektöründe, BÇS'nin ekolojik bağlamdaki katkılarının yeterince önemsenmemesi, rantın öncelikli hedef olarak kabul görmesi ile ilişkili olduğu düşünülmektedir. BÇS uygulamalarında yatıım maliyetinin yüksek olması, uzun vadede ortaya çıkan çevresel, ekonomik ve sosyal kazanımları örtük kılmaktadır.

Almanya, Danimarka, Kanada, Singapur, Japonya ve ABD'de BÇS'nin yaygınlaşması için merkezi ve yerel yönetimler tarafından farklı teşvik politikaları geliştirilmiştir. Türkiye'de ise BÇS kentleşme politikası olarak görülmemekte, BÇS için teşvik politikası bulunmamaktadır. Türkiye yapı sektöründeki Proje Geliştirme ve Tasarım Grubu paydaşları için BÇS, görselliği nedeniyle bir pazarlama unsuru olmaktadır.

Türkiye'deki yapı üretimi sektöründe üretim organizasyonu biçimleri, yapı üretimine katkı sağlayan paydaşların nasıl ve ne oranlarda sürece dâhil olabildiklerine göre çok değişik biçimler alabilmektedir. Bu durum, yapı üretimin küçük, orta ve büyük ölçekli olmasına göre daha da farklılaşabilmektedir. Yapı üretimi sürecinde paydaşların sorumluluk ve yetkilerinin netleştirilmesi ve paydaşlar arası koordinasyonların sistematik, kontrollü ve denetlenebilir bir zemine kavuşabilmesi önemlidir. Danışman ve denetleyici paydaşların proje koordinasyonuna dâhil edilmesini zorunlu tutulabilecek proje yönetimi modelleri, BÇS uygulamaları gibi detaylı üretimlerin sağlıklı olmasında etkili olacaktır.

Kuzey Amerika ve Japonya gibi ülkeler için BÇS konusunda kaynak olan FLL kılavuzu ve ASTM birliği tarafından BÇS yapımının ayrıntılı olarak açıklandığı kılavuzların yayınlanması, BÇS uygulamalarının yaygınlaşmasına katkı sağlamıştır. Uygulamalar için geliştirilecek detaylı standartlar ile süreçlere yönelik geliştirilecek yasal düzenlemelerin Türkiye'de BÇS'nin yaygınlaşmasına katkı sağlayacağı düşünülmektedir. Ayrıca, bu standart ve yasal düzenlemelerin yapı denetim süreçleri ile desteklenmesi gereklidir.

BÇS uygulamalarının yapılacağı binalarda harçların azaltılması, işverenlere, uygulamacılara, işletmecilere ve mal sahiplerine vergi muafiyetlerinin sağlanması, bu sistemlerin yaygınlaşmasında önemli adımlar olabilir. Özellikle nihai kullanıcıyı da özendirecek, emlak vergisi indirimi ve aidat bedellerinin düşürülmesine yönelik politikaların geliştirilmesidir. BÇS'nin budama ve gübreleme gibi bakım işlerinde nihai kullanıcıların mali yükünü hafifletmek adına yerel idare desteği sağlanabilir.

BÇS'nin uygulama ve işletme süreçlerinde sağladıkları yararlar açısından daha etkili ve verimli sonuçlar ortaya koyabilmelerine yönelik araştırmaların yapılması önemlidir. Araştırma ve geliştirme faaliyetlerinde akademik paydaşlarla, çevreye duyarlı politikaların yaygınlaştırılabilmesinde yerel yönetimlerle, BÇS pazarının gelişebilmesinde üretici ve uygulamacılarla işbirliği gereklidir. Araştırmacıların piyasadaki uygulamalardan kopukluğunun önüne geçilmelidir. BÇS'nin gelişebilmesi için mevcut paydaşların yanı sıra konuya destek verebilecek ziraat mühendisleri gibi farklı disiplinlerde uzmanlıkların süreçlere dâhil edilmeleri yararlı olacaktır. 


\section{KAYNAKLAR}

Araştırma, Geliştirme Ve Tasarım Faaliyetlerinin Desteklenmesine İlişkin Uygulama Ve Denetim Yönetmeliği: [http://www.resmigazete.gov.tr/eskiler/2016/08/20160810-7.htm] (Erişim tarihi 26.05.2019, 13:55).

Berardi Umberto, GhaffarianHoseini AmirHosein, GhaffarianHoseini Ali, (2014) Stateof-the-Art Analysis Of The Environmental Benefits Of Green Roofs, Applied Energy $115,411-428$.

Brennelsen Stephan,(2003) The Benefits of Biodiversity From Green Roofs: Key Design Consequences, In Proc. Of 1st North American Green Roof Conference: Greening rooftops for sustainable communities, (29-30 May 2003) Chicago. The Cardinal Group, Toronto; p.323-329.

Bruderman Thomas, Sangkakool Tachaya., (2017) Green roofs in temperate climate cities in Europe - An analysis of keydecision factors; Urban Forestry \& Urban Greening 21; 224-234 http://dx.doi.org/10.1016/j.ufug.2016.12.008

Clark Corrie, Adriaens Peter, Talbot F.Brian, (2008) Green Roof Valuation: A Probabilistic Economic Analysis Of Environmental Benefits, Environmental Science Technology, 42 (6) 2155-2161

Chen Xi, Shual Chenyang, Chen Zhenhao, Zhang Yu., (2019) What Are The Root Causes Hindering The Implementation Of Green Roofs In Urban China? Science of the Total Environment 654, 742-750 https://doi.org/10.1016/j.scitotenv.2018.11.051

Connelly Maureen, Hodgson Murray., (2013) Experimental Investigation of The Sound Transmission of Vegetated Roofs. Applied Acoustics, 74:1136-43. https://doi.org/10.1016/j.apacoust.2013.04.003

Dewey W. Daniel., Johnson Paul G.., Kjelgren Roger K.., (2004) Species Composition Changes in a Rooftop Grass and Wildflower Meadow, Native Plants, 5:56-65.

Ekşi Mert., Uzun Adnan., (2016) Yeşil Çatı Sistemlerinin Su Ve Enerji Dengesi Açısından Değerlendirilmesi; Journal of the Faculty of Forestry Istanbul University, 66(1): 119-138

Ekşi Mert, (2014) Çatı Bahçesi Kavramı Ve Terim Kullanımı Üzerine Bir Değerlendirme, Avrasya Terim Dergisi, 2 (2):26-35

EPA. (2007). Heat Island Effect. from Environmental Protection Agency (EPA): [www.epa.gov] (Erişim tarihi 20.08.2011, 11:54).

Getter Kristin L., Rowe D. Bradley., Cregg, B.M., (2009). Solar Radiation Intensity Influences Extensive Green Roof Plant Communities; Urban Forestry and Urban Greening 8 (4), 269-281. https//doi.org/10.1016/j.ufug.2009.06.005

Hui, Sam C.M., (2006). Benefits And Potential Applications Of Green Roof Systems In Hong Kong; Proceedings of the 2nd Megacities International Conference 2006, 1-2 December. 351-60. 
İski Atıksuların Kanalizasyona Deşarj Yönetmeliği: [http://www.resmigazete.gov.tr/eskiler/2017/06/20170623-8.htm] (Erişim tarihi 26.05.2019, 16:10)

İstanbul İmar Yönetmeliği:

[http://www.resmigazete.gov.tr/eskiler/2018/05/20180520-4.htm] (Erişim tarihi 26.05.2019, 17:00)

Kaymak Yanar., (2015) Çevre Odaklı Mimari Tasarım Yaklaşımı Kapsamında Yeşil Çatılar Ve Türkiye Ölçeğinde Uygulanabilirliği Üzerine Bir Araştırma, yayınlanmamış Yüksek Lisans Tezi, Yıldız Teknik Üniversitesi, Fen Bilimleri Ens.

Li W. C., Yeung K.K.A., A (2014) Comprehensive Study Of Green Roof Performance From Environmental Perspective; International Journal of Sustainable Built Environment 3, 127-134 http://dx.doi.org/10.1016/j.ijsbe.2014.05.001

Mıaomıao He., (2011) Promoting Green Roofs In China: A Comparison Of Green Roof Policies In The Unıted States (U.S.) And China, yayınlanmamış Yüksek Lisans Tezi, University of Florida.

Ngan Goya., (2004) Green Roof Policies: Tools for Encouraging Sustainable Design. [https://www.coolrooftoolkit.org/knowledgebase/green-roof-policies-tools-for-

encouraging-sustainable-design/] Erişim Tarihi: (14.08.2018, 21:00)

Peck Steven W., Callaghan Chris., (1999) Greenbacks From Green Roofs: Forging A New Industry In Canada, Research report for Canada Mortgage and Housing Corporation. https://www.osti.gov/etdeweb/biblio/20052181 (Erişim tarihi 22 Temmuz 2020, 13:30)

Planlı Alanlar İmar Yönetmeliği: [https://www.mevzuat.gov.tr/mevzuat?MevzuatNo=23722\&MevzuatTur=7\&MevzuatTert ip=5] (Erişim tarihi 02.09.2020; 14:00)

Sangkakool Tachaya., Techato Kuaanan., Zaman Rafia., Brudermann Thomas., (2018) Prospects of green roofs in urban Thailand - A multi-criteria decision analysis; Journal of Cleaner Production 196 400-410 https://doi.org/10.1016/j.jclepro.2018.06.060

Santamourıs Mat., Energy and Climate in the Urban Built Environment, James and James Science Publishers, London, 2001.

Shafıque Muhammad., Kım Reeho., Rafıq Muhammad., (2018) Green Roof Benefits, Opportunities And Challenges - A Review; Renewable and Sustainable Energy Reviews 90 757-773, https://doi.org/10.1016/j.rser.2018.04.006

Townshend, Derek., (2007). Study On Green Roof Application In Hong Kong; Architectural Services Department, Urbris Limited http://www.archsd.gov.hk/media/11630/green_roof_study_final_report.pdf.

(Erişim tarihi 22 Temmuz 2020, 15:36) 
Türkeri Nil, Altun M. Cem, Göçer Caner., (2011) İstanbul'da Mevcut Çatı Sistemi ile Bitkilendirilmiş Çatı Sistemi Isıl Performanslarının Karşılaştırmalı Değerlendirilmesi; Megaron, 6(1): 21-29

Ulubeyli Serdar., Arslan Volkan., (2017) Economic Viability Of Extensive Green Roofs Through Scenario And Sensitivity Analyses: Clients' Perspective; Energy and Buildings; 139 314-325 http://dx.doi.org/10.1016/j.enbuild.2017.01.042

Vijayaraghavan K., (2016) Green roofs: A critical review on the role of components, benefits, limitations and trends; Renewable and Sustainable Energy Reviews 57, 740752

Yang Hong Seok., Kang Jian., Chol Min Sung, (2012) Acoustic Effects Of Green Roof Systems On A Low- Profiled Structure At Street Level. Build Environment;50:44-55. https://doi.org/10.1016/j.buildenv.2011.10.004

Yang Jun, Yu Qian, Gong Peng., (2008) Quantifying air pollution removal by green roofs in Chicago. Atmospheric Environment;42:7266-73. 